\title{
A simple and inexpensive modified CTAB and silica particles-based method for recalcitrant plant genomic DNA isolation
}

\author{
W. Huanca-Mamani, E. Choque-Ayaviri and S. Cárdenas-Ninasivincha \\ Laboratorio de Biología Molecular de Plantas, Departamento de Producción \\ Agrícola, Facultad de Ciencias Agronómicas, Universidad de Tarapacá, \\ Arica, Chile \\ Corresponding author: W. Huanca-Mamani \\ E-mail:whuanca@uta.cl \\ Genet. Mol. Res. 19 (1): gmr18510 \\ Received October 28, 2019 \\ Accepted January 31, 2020 \\ Published February 29, 2020 \\ DOI http://dx.doi.org/10.4238/gmr18510
}

\begin{abstract}
In this study, a modified CTAB method combined with sodium sulphite and silica particles for the extraction of highquality genomic DNA of recalcitrant plants such as malva, coffee, avocado, mango, olive, jatropha and tillandsia is reported. Maceration with liquid nitrogen, phenol treatment, RNase digestion and the ethanol precipitation step are eliminated using this methodology. The quality of the isolated DNA permits downstream molecular applications including AFLP, restriction, ligation and PCR amplification and sequencing of plant barcode genes (mat $K$ and $r b c L$ ). The cost per sample (about US\$ 0.14) is quite low compared to any commercially available kit. This methodology is reproducible and could be used for a broad spectrum of woody plants with a high content of polyphenols and polysaccharides compounds, without the need for a commercial kit or expensive reagents, providing a viable alternative for laboratories with low budgets.
\end{abstract}

Key words: Recalcitrant plant; Genomic DNA extraction; CTAB sodium sulphite - silica based method 


\section{INTRODUCTION}

The isolation of high quality of plant genomic DNA is an essential prerequisite in molecular biology work, because the presence of enzyme inhibitors such as proteins, polyphenols and polysaccharides alkaloids and tannins may coprecipitate with DNA during commercial or homemade procedures and interfere with the enzymatic activity in many molecular techniques (Pirttila et al., 2001). Isolation of high-quality nucleic acids from plant tissues rich in polysaccharides and polyphenols is often a difficult task.

Typically, homemade plant DNA isolation methods are cheap and very efficient at producing DNA samples, but they are usually time-consuming and less efficient in the removal of protein, carbohydrates, and other organic contaminants from samples, thus, causing enzymatic inhibition in subsequent molecular analyses (Echevarria-Machado et al., 2005; Benjak et al., 2006). Commercial DNA extraction kits are generally fast but quite expensive; additionally they often use toxic chaotropic salts to bind DNA to silica-based columns and generate large quantities of contaminant wastes such as beads, filters, columns, and microcentrifuge tubes.

Several methodologies to isolate genomic DNA from plants have been reported; however, there are few reports related to obtaining sufficient quantities of high-quality DNA for molecular work from recalcitrant species (Reddy, 2009; Azmat et al., 2012; Alexander 2016; Rezadoost et al., 2016; Arruda et al., 2017; Swetha et al., 2018), which contain comparatively high quantities of polysaccharides and secondary metabolites, posing problems in downstream applications of the DNA.

In this study, a new method to obtain good quality DNA from recalcitrant plants was developed. This method combines CTAB-sodium sulphite extraction and silicaparticles based protocols. The method is simple, inexpensive, efficient, and less hazardous to health than other methods described previously.

\section{MATERIAL AND METHODS}

\section{Plant material}

Fresh leaf samples were collected from several recalcitrant plant species with high levels of polysaccharides, polyphenols and other sticky substances: malva (Hibiscus sp.), olive (Olea europaea), avocado (Persea americana), mango (Mangifera indica), jatropha (Jatropha curcas) and coffee (Coffea arabica), located in the Botanical garden of Facultad de Ciencias Agronómicas (18³1'11" S; 70¹0'41" W), at Universidad de Tarapacá, Valle de Azapa, Arica-Chile. Leaf samples of tillandsia (Tillandsia landbeckii) were collected from Pampa Dos Cruces (18²8'43" S; 705'16" W).

\section{DNA extraction protocol}

The following protocol was developed for extracting good quality DNA from recalcitrant plant leaves. Collect two-discs of leaf samples (around $50 \mathrm{ng}$ ) using the lid of a $1.5 \mathrm{~mL}$ Eppendorf tube to punch of leaf material straight into the tube. This extraction not only ensures a uniform sample size, but it also reduces contamination. Add $400 \mu \mathrm{L}$ lysis buffer (2\% CTAB, $100 \mathrm{mM}$ Tris-HCl, $2.0 \mathrm{M} \mathrm{NaCl}, 1 \%$ PVP-40, $20 \mathrm{mM}$ disodium salt of 
ethylenediaminetetraacetic acid $\left(\mathrm{Na}_{2}\right.$ EDTA), $\left.0.2 \% \mathrm{LiCl}\right)$; the $\mathrm{pH}$ was adjusted to 8.0 before autoclaving and $1 \%$ sodium sulphite added. Grind the samples using a plastic pestle. Mix the sample by vortex and then incubate at $65^{\circ} \mathrm{C}$ for at least $30 \mathrm{~min}$. Centrifuge the mixture at $10,000 \mathrm{rpm}$ for $5 \mathrm{~min}$ at room temperature (RT) and transfer the supernatant into a new $1.5 \mathrm{~mL}$ Eppendorf tube. Add an equal volume of chloroform-isoamyl alcohol (24:1 v/v) and mix gently by inverting the tube to form an emulsion. Centrifuge for $10 \mathrm{~min}$ at $12,000 \mathrm{rpm}$ and carefully transfer the supernatant solution into a new $1.5 \mathrm{~mL}$ Eppendorf tube. Add an equal volume of $3 \mathrm{M} \mathrm{NaCl}$ and $25 \mu \mathrm{L}$ silica matrix $(1 \mathrm{mg} / \mathrm{mL})$, mix it in a vortex and incubate for $5 \mathrm{~min}$ at RT. Centrifuge at $12,000 \mathrm{rpm}$ for $11 \mathrm{~s}$ and discard the supernatant solution. Wash the pellet twice with $500 \mu \mathrm{L}$ washing solution $(50 \%$ ethanol, $10 \mathrm{mM}$ Tris$\mathrm{HCl}, \mathrm{pH} 7.5,100 \mathrm{mM} \mathrm{NaCl}, 1 \mathrm{mM}$ EDTA). Dry the pellet at $37^{\circ} \mathrm{C}$. Elute the DNA resuspending the silica matrix pellet with $50 \mu \mathrm{L}$ of distilled deionized $\mathrm{H}_{2} \mathrm{O}$ and then incubate at $65^{\circ} \mathrm{C}$ for $5 \mathrm{~min}$. Centrifuge at $12,000 \mathrm{rpm}$ for $2 \mathrm{~min}$ at room temperature. Carefully transfer approximately $45 \mu \mathrm{L}$ supernatant containing the eluted DNA into new tubes without disturbing the silica particles.

\section{Preparation of silica matrix}

The procedure to prepare the size-fractioned silica particles was undertaken according to Li et al. (2010). Mix $5 \mathrm{~g}$ of silicon dioxide (S5631, Sigma-Aldrich, Saint Louis, MO, USA) with $50 \mathrm{~mL}$ sterile water in a $50 \mathrm{~mL}$ Falcon tube and allow to settle overnight. Remove the supernatant containing fine silica particles. This process guarantees that the silica particles used in the purification steps have a proper size, between 1 and 5 $\mu \mathrm{m}$, that can be recovered by centrifugation. Re-suspend the pellet in $50 \mathrm{~mL}$ sterile water and re-settle overnight. Remove the supernatant and finally, re-suspend the pellet in $50 \mathrm{~mL}$ sterile water.

\section{DNA amplification and sequencing reactions}

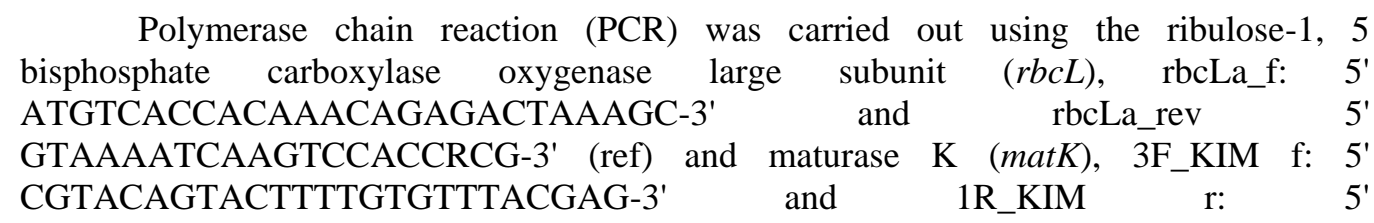
ACCCAGTCCATCTGGAAATCTTGGTTC-3' (Costion et al., 2011) primers to yield approximately 550 and 850 bp fragments, respectively. Each PCR reaction contained $1 \mathrm{X}$ PCR buffer (KCl), $2.5 \mathrm{mM} \mathrm{MgCl}, 0.25 \mathrm{mM}$ each dNTP, $0.1 \mu \mathrm{M}$ each primer, 1 unit of Taq DNA polymerase (Thermo Scientific) and $1 \mu \mathrm{L}$ DNA extract. PCR cycling consisted of 5 minutes initial denaturation at $94^{\circ} \mathrm{C}$, then 35 cycles of 30 seconds at $94^{\circ} \mathrm{C} ; 30$ seconds at $55^{\circ} \mathrm{C} ; 30$ seconds at $72^{\circ} \mathrm{C}$ and a final elongation step of 2 minutes at $72^{\circ} \mathrm{C}$. PCR blank controls were incorporated. The amplified products were separated by electrophoresis on $1.5 \%$ agarose gels stained withGel-Red (Biotium). Reactions containing PCR products of the expected size were directly sequenced by a commercial facility (Macrogen Inc., South Korea). 


\section{AFLP assays}

AFLP analyses were performed following the methodology described by Vos et al. (1995). In short, $200 \mathrm{ng}$ of genomic DNA were double-digested in a final volume of $15 \mu \mathrm{L}$ at $37^{\circ} \mathrm{C}$ with EcoRI and MseI (New England Biolabs), followed by ligation of EcoRI and MseI adapters in the same reaction. Pre-selective PCR amplifications were performed using primer EcoRI (+0) and MseI (+0) carrying no selective nucleotide. The selective PCR amplification was performed using the EcoRI (+3) and MseI (+3) primer with three selective nucleotides at $3^{\prime}$ ends. Final amplification products were separated on $6 \%$ polyacrylamide gels electrophoresis in $0.5 \mathrm{X}$ Tris-borate-EDTA buffer using a 1,000 bp DNA marker (BioLabs); $0.2 \%$ silver nitrate was used for staining.

\section{RESULTS}

This method was tested with several kinds of recalcitrant plants, and the integrity of the genomic DNA isolated was visualized on $1.2 \%$ agarose gels (Figure 1). DNA samples showed intact/clear bands on agarose gels, suggesting that little or no DNA degradation had occurred during the extraction. Spectrophotometer analysis showed that the $\mathrm{A}_{260} / \mathrm{A}_{280}$ ratios of DNA samples ranged from 1.68 to 2.01 for $P$. americana and $O$. europaea, respectively, suggesting that the DNA isolated by this approach was pure and may be used for further analysis (Table 1). The yields were between 85 and $223 \mathrm{ng} / \mu \mathrm{l}$ for $M$. indica and Hibiscus sp., respectively (Table 1).

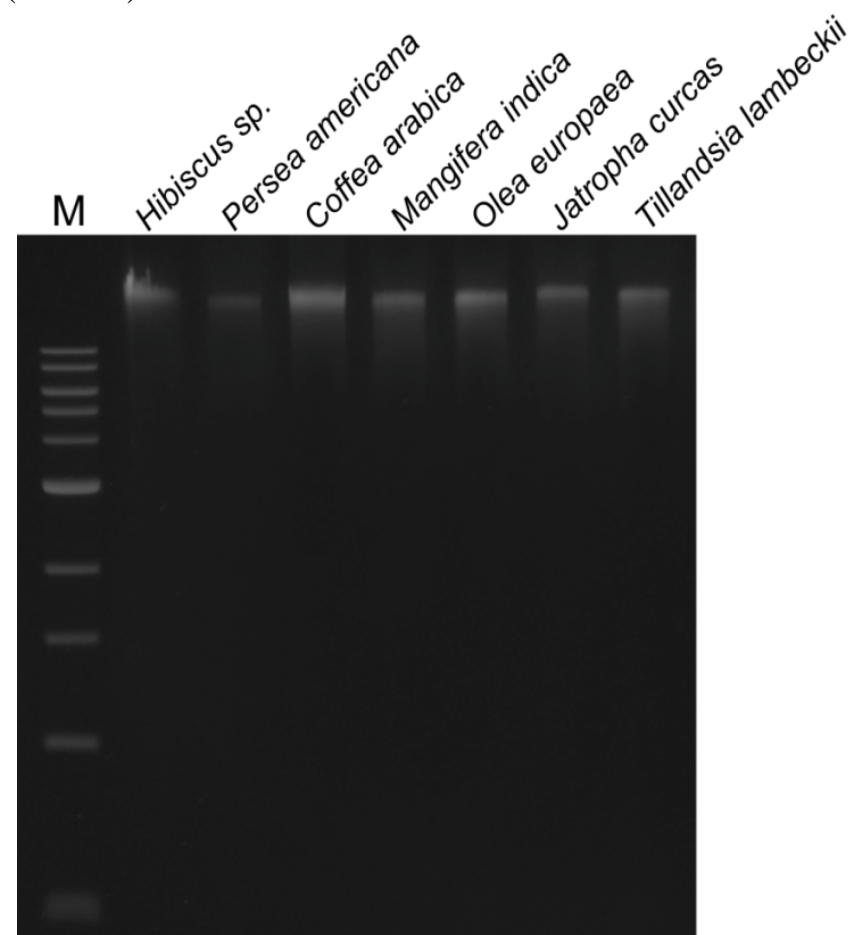

Figure 1. Total genomic DNA analysis extracted from recalcitrant plants using the CTAB-sodium sulphite-silica method. M: 1 kb DNA ladder. 
Table 1. Yield and purity of plant genomic DNA. The values correspond to the average of three independent samples.

\begin{tabular}{|c|c|c|}
\hline Plant & $\begin{array}{c}\text { Absorbency ratio } \\
\left(\mathrm{A}_{260} / \mathrm{A}_{280}\right)\end{array}$ & $\begin{array}{c}\text { DNA yield } \\
(\mathrm{ng} / \mu \mathrm{L})\end{array}$ \\
\hline Hibiscus sp. & $1.72 \pm 0.08$ & $223 \pm 25$ \\
\hline Persea americana & $1.68 \pm 0.06$ & $212 \pm 51$ \\
\hline Coffea arabica & $1.76 \pm 0.09$ & $182 \pm 26$ \\
\hline Mangifera indica & $1.90 \pm 0.12$ & $85 \pm 8$ \\
\hline Olea europaea & $2.01 \pm 0.28$ & $107 \pm 19$ \\
\hline Jatropha curcas & $1.91 \pm 0.06$ & $130 \pm 24$ \\
\hline Tillandsia lanbeckii & $1.76 \pm 0.09$ & $142 \pm 3$ \\
\hline
\end{tabular}

PCR, sequencing and AFLP evaluated the quality of the genomic DNA isolated using this method and its usefulness for basic molecular analysis. Since isolated plant genomic DNA is routinely used for cloning, the quality of the DNA was evaluated by PCR. Single and specific PCR fragments of the expected sizes, approximately 550 and 850 bp of $r b c L a$ and $M a t K$, respectively, were successfully amplified in all samples analyzed (Figure 2). These PCR products were entirely sequenced in both strands, producing read lengths of 550 and $850 \mathrm{bp}$, respectively, during DNA sequencing analysis (Figure 3), which also reflects the high quality of the DNA template generated by this method.

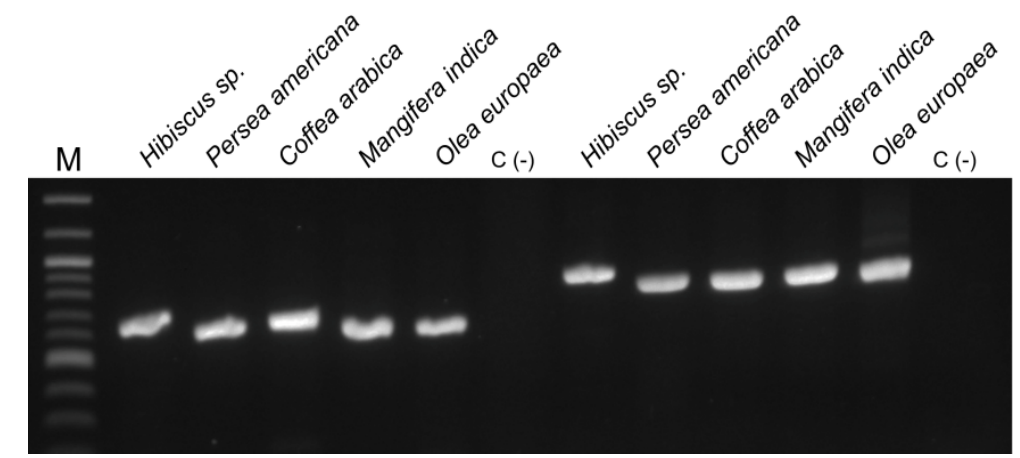

Figure 2. Amplification of the rbcLa (left side) and $M a t K$ (right side) fragment using total genomic DNA extracted from recalcitrant DNA with the CTAB- sodium sulphite-silica method. M: 100 bp DNA ladder.

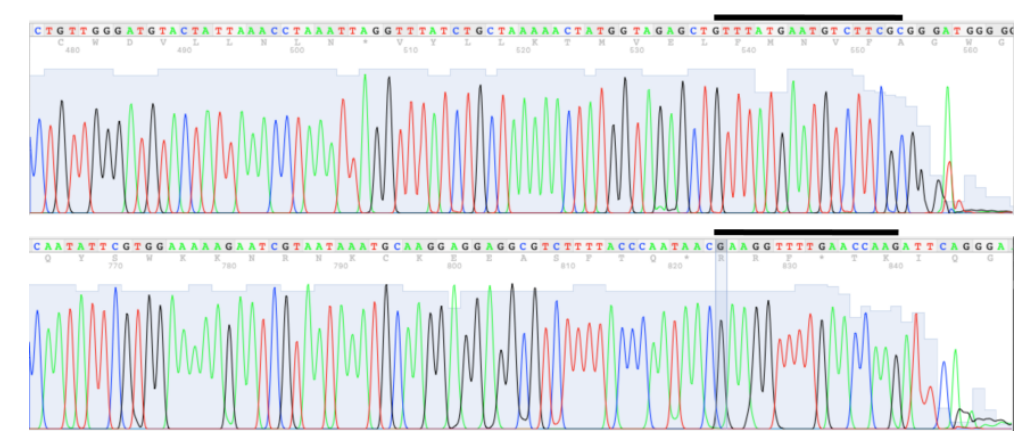

Figure 3. DNA sequencing of the rbcLa (upper panel) and MatK (lower panel) genes of coffee plants. The 3 '-end of each DNA sequencing result is shown with individual nucleotide peaks clearly distinguishable. Fragments of the primer sequence are indicated by a black line. The sequences were obtained using the same primers as for the original PCR. 
To evaluate the quality of the DNA extracted using this method, AFLP analysis on DNA extracted from hibiscus and olive were carried out. AFLP demands DNA of high molecular weight that is free from contamination. AFLP fingerprints resulting from selective amplification are shown (Figure 4). The presence of clear and well-differentiated band patterns reflects the efficiency of our method to produce genomic DNA with high purity suitable for several molecular studies.

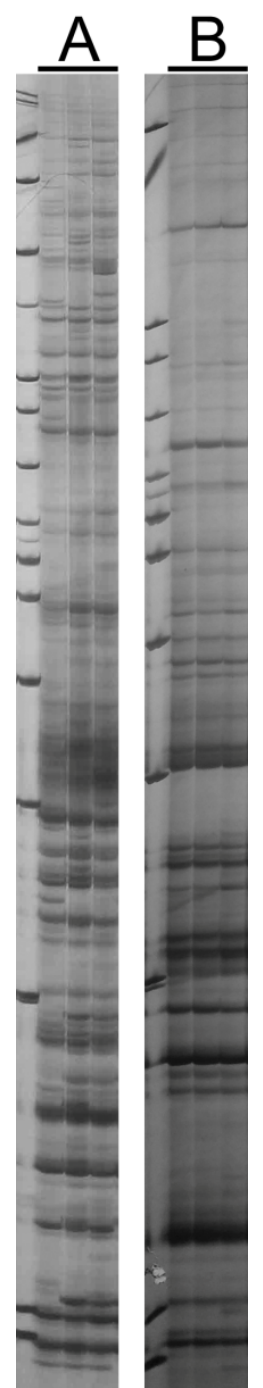

Figure 4. AFLP fingerprints in recalcitrant plants. A: AFLP of three individuals of hibiscus using combination E36-M60. B: AFLP in one individual of coffee was performed in triplicate using combination E35-M60.

\section{DISCUSSION}

A simple and efficient protocol for genomic DNA extraction is of great scientific value for a wide range of applications. In this study, the effectiveness of a low-cost and 
straightforward procedure to successfully extract genomic DNA from recalcitrant plants was developed and evaluated. Perennial woody plants such as olive, malva, coffee, mango, avocado, jatropha and desert plants such as tillandsia were chosen because DNA extraction is problematic, due to the high concentration of polysaccharide, polyphenols and other secondary metabolites. Also, the high content of gummy, mucilaginous substances in malvacea represented a good system to demonstrate the effectiveness of this method.

The CTAB-sodium sulphite-silica particles DNA extraction protocol combines the CTAB-PVP method (Atashpaz et al., 2010), the silica binding procedure (Li et al., 2010) and the presence of sodium sulphite (Turaki et al., 2017). The CTAB-PVP method was previously developed to isolate bacterial genomic DNA and showed excellent results in several genomic DNA extractions of fungi (Huanca-Mamani et al., 2014) and insect larvae (Huanca-Mamani et al., 2015). Liquid nitrogen to grind the samples or ice is not required in this method. CTAB and PVP-40 were used to remove phenolic compounds and polysaccharides which can co-precipitate with the DNA and this way inhibits enzymatic reactions in subsequent analyses (Lodhi et al., 1994; Rouhibakhsh et al., 2008; Alexander, 2016). Particularly, PVP removes polyphenols and other resinous material by forming complex hydrogen bonds with phenols and co-precipitates with cell debris upon cell lysis (John, 1992; Puchooa and Venkatasamy, 2005). However, CTAB and PVP not guarantee the elimination of some polysaccharides, and lipids (Echevarria-Machado et al., 2005). The presence of $\mathrm{NaCl}$ at $2.0 \mathrm{M}$ helps to remove the polysaccharides efficiently (Sahu et al., 2012). The RNA is eliminated from samples through selective precipitation using $\mathrm{LiCl}$ present in the lysis buffer. The extraction buffer included sodium sulphite because sulphurcontaining reducing agents have been shown to be inhibitors of phenol-oxidase enzymes or reducing agents of their reactive quinone products (Whitlock et al., 2018). The $\beta$ mercaptoethanol is not used because it may be toxic to some extent (Rouhibakhsh et al., 2008).

Due to the ability of DNA to bind to silica in the presence of chaotropic salt (Boom et al., 1990), it has been widely used in DNA isolation, being a very efficient and rapid means to isolate DNA from several sources (Carter and Milton, 1993: Hoss and Paabo, 1993; Lakshmi et al., 1999; Li and Sheen, 2010). The most protocol use sodium iodide (NaI) or guanidine thiocyanate $(\mathrm{GuSCN})$ as the chaotropic salt, which are expensive chemicals. It was replaced with nonchaotropic salt $\mathrm{NaCl}$ to facilitate DNA binding to silica, because is a cheaper option and the solution is stable at room temperature (Lakshmi et al., 1999; Rohland and Hofreiter, 2007).

The yield of DNA obtained from several samples was between 85 and $223 \mathrm{ng} / \mathrm{ul}$, corresponding to mango and hibiscus, respectively. The absorbance ratio $\left(\mathrm{A}_{260} / \mathrm{A}_{280}\right)$ was in ranged 1.68 and 2.01 indicating the purity of the DNA obtained. Agarose gels showed that, this method gives rise a successful nucleic acid extraction, producing a purified DNA of high molecular weight, non-degraded and free from RNA contamination (Figure 1). The amplification of DNA through PCR of the $r b c L$ and $c y t b$ genes produced expected fragments of 550 and $850 \mathrm{pb}$, respectively, in all samples tested (Figure 2). Last part of the chromatogram of the sequence amplified of these genes showed the order of nucleotide sequence and the quality of the sequences (Figure 3). The AFLP fingerprints obtained from DNA purified using our method were of sufficient quality to allow the genotyping, which could help to identify and characterize species as part of the germplasm conservation studies (Figure 4). PCR amplifications from several locis, or AFLP fingerprints were 
obtained after the DNA samples had been stored for at least one and half year (data not shown), indicating that DNA isolated by this method is suitable for extended storage periods. Amplification and further sequencing of $r b c L$ and $M a t K$ genes and the AFLP analysis performed, provides evidence of the efficiency of this method and its applicability in a molecular analysis like genetic diversity studies and DNA barcoding.

The advantage of this method is its low cost. The cost of employing this protocol is approximately a $1 / 14$ of the cost of the cheapest commercially available kits. Concerning commercial kits, the cost per sample starts from US\$2, while using our methods, the cost per sample is around US\$ 0.14. While the time taken per sample (approx. $50 \mathrm{~min}$ ) is similar compared to commercial kits, we believe that in our method, efficient to obtain good quality of DNA from recalcitrant plant, the time can be sacrificed to save a considerable amount of money.

In conclusion, we developed an efficient, cost-effective and highly reproducible protocol for recalcitrant plant genomic DNA isolation that can be used for a broad spectrum of woody plant species that have polyphenols and polysaccharide compounds. Maceration with liquid nitrogen, phenol treatment, RNase digestion and the ethanol precipitation step are all eliminated using this methodology. All solutions used are made from common and inexpensive chemicals that are stable at room temperature and are less hazardous to health than those of other methods described previously. Using this methodology, it is possible to prepare high-quality recalcitrant plant DNA without the need for a commercial kit or expensive reagents, which is an important consideration in many laboratories in developing countries with low budgets.

\section{ACKNOWLEDGMENTS}

The authors would like to thank the support from Programa Investigador Asociado, Universidad de Tarapacá, Convenio de Desempeño Regional UTA1795 and UTA1799.

\section{CONFLICTS OF INTEREST}

The authors declare no conflict of interest.

\section{REFERENCES}

Alexander L (2016). Rapid, Effective DNA Isolation from Osmanthus via Modified Alkaline Lysis. J. Biomol. Tech. 27: 53-60.

Arruda SR, Pereira DG, Silva-Castro MM, Brito MG, et al. (2017). An optimized protocol for DNA extraction in plants with a high content of secondary metabolites, based on leaves of Mimosa tenuiflora (Willd.) Poir. (Leguminosae). Genet. Mol. Res. 16: gmr16039063.

Atashpaz S, Khani S, Barzegari A, Barar J, et al. (2010). A robust universal method for extraction of genomic DNA from bacterial species. Mikrobiologiia. 79: 538-542.

Azmat MA, Khan IA, Naseer Cheema HM, Rajwana IA, et al. (2012). Extraction of DNA suitable for PCR applications from mature leaves of Mangifera indica L. J. Zhejiang Univ-Sci. B13: 239-243.

Benjak A, Konradi J, Blaich R and Forneck A (2006). Different DNA extraction methods can cause different AFLP profiles in grapevine (Vitis vinifera L.). Vitis. 45: 15-21.

Boom R, Sol CJ, Salimans MM, Jansen CL, et al. (1990). Rapid and simple method for purification of nucleic acids. $J$. Clin. Microbiol. 28: 495-503.

Carter MJ and Milton ID (1993). An inexpensive and simple method for DNA purifications on silica particles. Nucleic Acids Res. 21: 1044. 
Costion C, Ford A, Cross H, Crayn D, et al. (2011). Plant DNA barcodes can accurately estimate species richness in poorly known floras. PLoS One. 6: e26841.

Echevarria-Machado I, Sánchez-Cach LA, Hernández-Zepeda C, Rivera-Madrid R, et al. (2005). A simple and efficient method for isolation of DNA in high mucilaginous plant tissues. Mol. Biotechnol. 31: 129-135.

Hoss M and Paabo S (1993). DNA extraction from Pleistocene bones by a silica-based purification method. Nucleic Acids Res. 21: 3913-3914.

Huanca-Mamani W, Martínez RS and Sepulveda-Chavera G (2014). A fast and efficient method for total DNA extraction from soil filamentous fungi. IDESIA. 32: 75-78.

Huanca-Mamani W, Rivera-Cabello D and Maita-Maita J (2015). A simple, fast, and inexpensive CTAB-PVP-silica based method for genomic DNA isolation from single, small insect larvae and pupae. Genet. Mol. Res. 14: 80018007.

John ME (1992). An efficient method for isolation of RNA and DNA from plants containing polyphenolics. Nucleic Acids Res. 20: 2381.

Lakshmi R, Baskar V and Ranga U (1999). Extraction of superior-quality plasmid DNA by a combination of modified alkaline lysis and silica matrix. Anal. Biochem. 272: 109-112.

Li JF, Li L and Sheen J (2010). Protocol: a rapid and economical procedure for purification of plasmid or plant DNA with diverse applications in plant biology. Plant Methods. 6: 1.

Lodhi MA, Ye GN, Weeden NF and Reisch BI (1994). A simple and efficient method for DNA extraction from gravepine cultivars and Vitis species. Plant Mol. Biol. Rep. 12: 6-13.

Pirttilä MA, Hirsikorpi M, Kämäräinen T, Jaakola L, et al. (2001). DNA isolation methods for medicinal and aromatic plants. Plant Mol. Biol. Rep. 19: 273.

Puchooa D and Venkatasamy K (2005). A protocol for the isolation of DNA from Trochetia boutoniana. Int. J. Agric. Biol. 7: 82-85.

Rezadoost MH, Kordrostami M and Kumleh HH (2016). An efficient protocol for isolation of inhibitor-free nucleic acids even from recalcitrant plants. 3 Biotech. 6: 61.

Reddy J (2009). A comprehensive nethod to isolate high quality DNA from the cultivars of Hibiscus. Int. J. Biotechnol. Appl. 1:1-9.

Rohland N and Hofreiter M (2007). Comparison and optimization of ancient DNA extraction. Biotechniques. 42: 343-52.

Rouhibakhsh A, Priya J, Periasamy M, Haq QMI, et al. (2008). An improved DNA isolation method and PCR protocol for efficient detection of multicomponents of begomovirus in legumes. J. Virol. Methods. 147: 37-42.

Sahu SK, Thangaraj M and Kathiresan K (2012). DNA extraction protocol for plants with high levels of secondary metabolites and polysaccharides without using liquid nitrogen and phenol. ISRN Mol Biol. doi: $10.5402 / 2012 / 205049$.

Swetha VP, Parvathy VA, Sheeja TE and Bhas S (2018). Isolation and amplification of genomic DNA from nutmeg mace. Indian J. Biotechnol. 17: 533-537.

Turaki A, Ahmad B, Magaji U, Abdulrazak U, et al. (2017). Optimised cetyltrimethylammonium bromide (CTAB) DNA extraction method of plant leaf with high polysaccharide and polyphenolic compounds for downstream reliable molecular analyses. Afr. J. Biotechnol. 16: 1354-1365.

Vos P, Hogers R, Bleeker M, Reijans M, et al. (1995). AFLP: a new technique for DNA fingerprinting. Nucleic Acids Res. 23: 4407-4414.

Whitlock R, Hipperson H, Mannarelli M and Burke T (2008). A high-throughput protocol for extracting high-purity genomic DNA from plants and animals. Mol. Ecol. Resour. 8: 736-41. 